\title{
ДО ПИТАННЯ ГЕНДЕРНИХ ОСОБЛИВОСТЕЙ КЛІНІЧНОГО ПЕРЕБІГУ ТА ЛІКУВАЛЬНОЇ ТАКТИКИ ПРИ ГОСТРОМУ КОРОНАРНОМУ СИНДРОМІ
}

\author{
ОМ. І. Швед, С. Й. Липовецька, С. М. Геряк, Л. В. Левицька
}

ДВНЗ «Тернопільський державний медичний університет імені І. Я. Горбачевського МОз України»

РЕзюМЕ. Серцево-судинні захворювання займають провідне місце серед причин смертності як у чоловіків, так і в жінок. Проте гострий коронарний синдром у жінок часто залишається не до кінця діагностованим і не лікованим через недостатнє усвідомлення цієї проблеми самими жінками, наявність атипових симптомів, зволікання з встановленням правильного діагнозу та рідше застосування інвазивних методів лікування.

У статті висвітлені основні особливості клінічного перебігу гострого коронарного синдрому у жінок, зокрема інфаркту міокарда без обструкції коронарних артерій, особливостей диференційної діагностики. Наголошено на спільних принципах діагностики і програмах ведення пацієнтів обох статей, незалежно від наявності певних гендерних розбіжностей, а також наведено перелік, показання до застосування і дози фібринолітичних, антикоагулянтних та антиагрегантних засобів з позицій доказової медицини.

КЛючОВІ СЛОВА: гострий коронарний синдром; інфаркт міокарда без обструкції коронарних артерій; перкутанні коронарні втручання; фібриноліз.

Вступ. Серцево-судинні захворювання займають провідне місце серед причин смертності як у чоловіків, так і в жінок. Разом з тим, незважаючи на високу ймовірність розвитку гострого коронарного синдрому (ГКС) у жінок, цей стан у них часто залишається не до кінця діагностованим і не лікованим. Причинами такої ситуації вважають, зокрема, недостатн $є$ усвідомлення цієї проблеми самими жінками, наявність атипових симптомів, зволікання в часі із встановленням правильного діагнозу та, рідше, застосуванням інвазивних методів лікування. Як правило, ГКС у жінок розвивається у старшому віці, що пов'язують з наявністю у них певних гормональних особливостей. Проте з віком зростає частка інших факторів ризику, зокрема, цукровий діабет, артеріальна гіпертензія, захворювання периферійних і цереброваскулярних судин, які не лише затруднюють своєчасну діагностику ГКС, а й суттєво погіршують прогноз і підвищують смертність у жінок [2]. IXC у жінок часто маніфестує без значного коронарного стенозу, що підтверджується коронарографією. Саме у них більше виявляють мікросудинні ураження та дещо іншу морфологію атеросклеротичних бляшок 3 переважанням ендотеліальних ерозій та розвитком спонтанного розшарування стінки коронарної артерії [3]. Разом з тим, у нових рекомендаціях $\epsilon_{\mathrm{B}-}$ ропейського кардіологічного товариства щодо ведення пацієнтів із ГКС з елевацією сегмента ST за 2017 р. наголошено на спільних принципах діагностики і ведення для обох статей, незалежно від наявності певних гендерних розбіжностей [1].

Метою даного повідомлення $\epsilon$ аналіз особливостей клінічного перебігу ГКС у хворих жіночої статі, причин утруднень зі своєчасною діагностикою цього клінічного стану у жінок і з вибором адекватної лікувальної тактики.
Основна частина. Тривалі клінічні спостереження та аналіз даних спеціальної літератури дозволяють зробити висновок, що для жінок з ГКС у ранньому періоді характерні атипові симптоми, включаючи біль у спині, шиї, розлади травлення, задишку тощо, що часто призводить до зволікання із встановленням правильного діагнозу і вибором правильної тактики лікування. При аналізі рівнів смертності, зокрема при ГКС без елевації сегмента ST чи нестабільній стенокардії, виявлено, що у жінок вона вища. Разом з тим, доведені чіткі переваги ранньої та вчасної реваскуляризації міокарда для обох статей, що відображено у рекомендаціях із встановленням чітких часових рамок (табл. 1).

Ще однією особливістю клінічного прояву гострої форми IXC у жінок $\epsilon$ так званий інфаркт міокарда без обструкції коронарних артерій. Ця форма IXC зустрічається у 1-14 \% випадків всіх IM і виникає на фоні відсутності обструкції коронарної артерії понад 50 \%. Повідомляється, що серед жінок така форма IM зустрічається достовірно частіше. Наявність необструктивної IXC у пацієнтів із симптомами ішемії та ST-елевації чи їі еквівалентів не виключає атеротромботичної етіології, оскільки тромбоз сам по собі $\epsilon$ динамічним феноменом.

В рекомендаціях Європейського кардіологічного товариства (2017) пропонують дотримуватися наступних діагностичних критеріїв IM без обструкції коронарних артерій (MINOCA -Myocardial infarction with non-obstructive coronary arteries): наявність критеріїв ІМ відповідно до універсального визначення; відсутність обструкції більше 50 \% у будь-якій потенційно інфарктзалежній коронарній артерії; відсутність інших причин для гострої клінічної маніфестації. Наголошується, що 
Огляди літератури, оригінальні дослідження, погляд на проблему, ювілеї цей діагноз є робочим і вимагає від лікарів адекватного діагностичного пошуку (рис. 1, табл. 2). Від-

сутність правильного діагнозу часто призводить до зволікання чи неправильного лікування [1].

Таблиця 1. Рекомендації щодо своєчасної тактики ведення пацієнтів із ГКС і елевацією сегмента ST

\begin{tabular}{|l|c|}
\hline \multicolumn{1}{|c|}{ Дія } & Час \\
\hline Максимальний час від першого контакту з пацієнтом і ЕКГ до встановлення діагнозу & $\leq 10$ хв \\
\hline $\begin{array}{l}\text { Максимальний час затримки від встановлення діагнозу ГКС з елевацією сегмента SТ до } \\
\text { первинного ПКВ (ПКВ має переваги над фібринолізом, проте, якщо неможливо дотриматись } \\
\text { цього часу, перевагу має фібриноліз) }\end{array}$ & $\leq 120$ хв \\
\hline Максимальний час від діагнозу до встановлення стента в первинному центрі для проведення ПКВ & $\leq 60$ хв \\
\hline Максимальний час від діагнозу до встановлення стента у транспортованих пацієнтів & $\leq 90$ хв \\
\hline $\begin{array}{l}\text { Максимальний час затримки від діагнозу до болюсу або інфузії фібринолітика у центрах без } \\
\text { можливості ПКВ }\end{array}$ & $\leq 10$ хв \\
\hline Час від початку фібринолізу до оцінки його ефективності & $60-90$ хв \\
\hline Час затримки від фібринолізу до ангіографії (якщо фібриноліз успішний) & $2-24$ год \\
\hline
\end{tabular}

Підозра на ГКС з елевацією сегмента ST

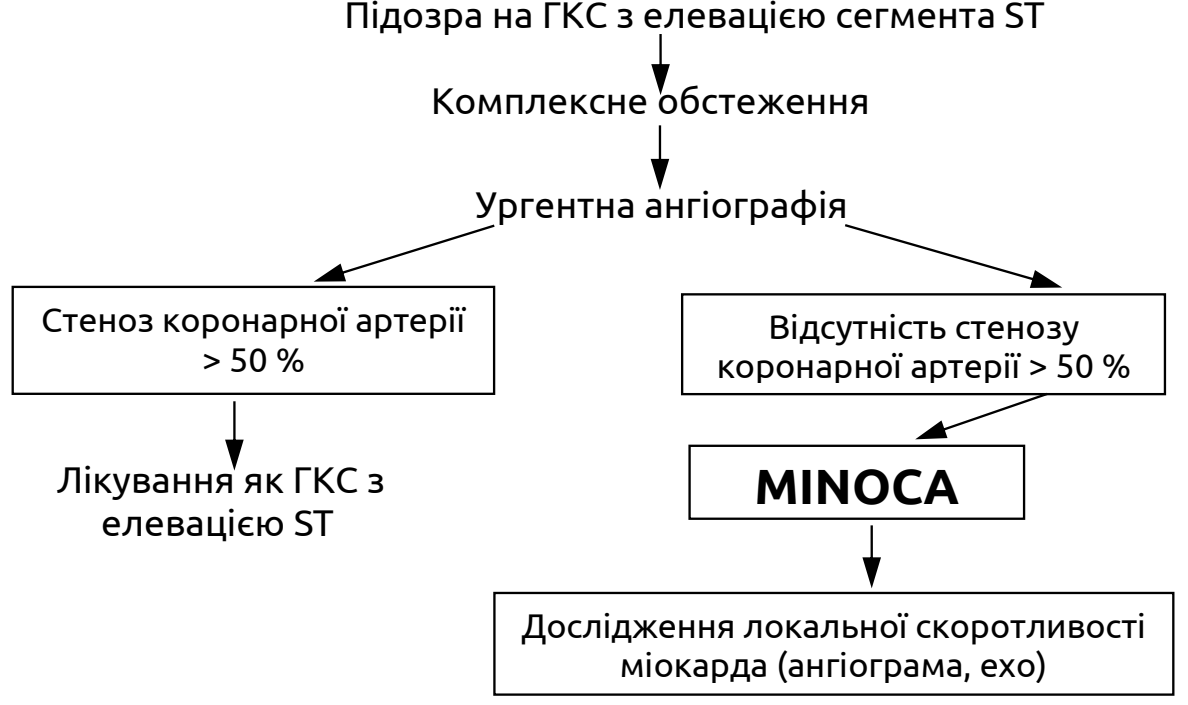

Рис. 1. Алгоритм ведення пацієнтів із підозрою на IM без обструкції коронарних артерій

Таблиця 2. Діагностичний пошук при IM без обструкції коронарних артерій

\begin{tabular}{|l|l|l|}
\hline \multicolumn{1}{|c|}{ Ймовірний діагноз } & \multicolumn{1}{|c|}{ Неінвазивні тести } & \multicolumn{1}{|c|}{ Інвазивні тести } \\
\hline Міокардит & $\begin{array}{l}\text { Трансторакальна ехокардіоскопія (ТТ ЕХОкс) } \\
\text { (перикардіальний випіт) } \\
\text { МРТ (міокардит, перикардит) }\end{array}$ & $\begin{array}{l}\text { Ендоміокардіальна біопсія } \\
\text { (міокардит) }\end{array}$ \\
\hline $\begin{array}{l}\text { Коронарні захворювання } \\
\text { (епікардіальне/ мікросудинне } \\
\text { ураження) }\end{array}$ & $\begin{array}{l}\text { ТТ ЕХОкс (порушення локальної } \\
\text { скротливості, джерело емболій) } \\
\text { МРТ (малі інфаркти) } \\
\text { Трансезофагальне ехо з контрастуванням } \\
\text { (Відкрите овальне вікно, дефект МПп) }\end{array}$ & $\begin{array}{l}\text { Внутрішньосудинний ультразвук } \\
\text { (розрив бляшок/розшарування) } \\
\text { Провокаційні тести (з } \\
\text { ергоном) (спазм) }\end{array}$ \\
\hline Міокардіальні захворювання & $\begin{array}{l}\text { ТТ ЕХОкс } \\
\text { МРТ (Такуцубо) }\end{array}$ & \\
\hline $\begin{array}{l}\text { Легеневий емболізм } \\
\text { киснюення балансу у доставці }\end{array}$ & $\begin{array}{l}\text { Д-димер } \\
\text { КТ } \\
\text { Скринінг на тромбофілію }\end{array}$ & $\begin{array}{l}\text { Дослідження крові } \\
\text { Екстракардіальні дослідження }\end{array}$ \\
\hline
\end{tabular}


Огляди літератури, оригінальні дослідження, погляд на проблему, ювілеї

Варто також зазначити, що суттєво вищий рівень перипроцедурних ускладнень (кровотечі і судинні ускладнення), реєструють у жінок 3 ГКС, порівняно із чоловіками. У кількох трайлах з досліджень ГКС із різною антикоагулянтною стратегією було показано, що жіноча стать $\epsilon$ незалежним предиктором кровотеч. «Global Registry of Acute Coronary Events» продемонстрував
OR - 1,71 (95 \% Cl 1,35-2,17) у жінок, порівняно 3 чоловіками $[2,4]$. Однак вживання інгібіторів глікопротеїнових рецепторів IIb/IIla не було незалежним ризиком для великих судинних ускладнень у жінок (табл. 3). Натомість лікування гепарином, порівняно із бівалірудином, було незалежним предиктором великих кровотеч (табл. 4) [5].

Таблиця 3. Дози антиагрегантів і антикоагулянтів для лікування пацієнтів при проведенні первинного ПКВ або при відсутності реперфузійної терапії

\begin{tabular}{|c|c|}
\hline $\begin{array}{l}\text { Антитромбоцитарні } \\
\text { препарати }\end{array}$ & $\begin{array}{c}\text { Дози парентеральних антикоагулянтів і антитромбоцитарних препаратів } \\
\text { при ПКВ }\end{array}$ \\
\hline $\begin{array}{l}\text { Ацетилсаліцилова } \\
\text { кислота }\end{array}$ & $\begin{array}{l}\text { Навантажувальна доза 150-300 мг перорально або 75-250 мг в/в, а потім } \\
\text { підтримувальна доза 75-100 мг/добу }\end{array}$ \\
\hline Тікагрелор & $\begin{array}{l}\text { Навантажувальна доза } 180 \text { мг перорально, а потім підтримувальна доза } 90 \text { мг } 2 \text { рази } \\
\text { на добу }\end{array}$ \\
\hline Клопідогрель & Навантажувальна доза 600 мг перорально, а потім підтримувальна доза 75 мг/добу \\
\hline \multicolumn{2}{|l|}{ Антикоагулянти } \\
\hline НФГ & $\begin{array}{l}\text { 70-100 ОД/кг в/в болюсно, якщо не використовуються інгібітори GP-рецепторів IIb/IIIa } \\
\text { тромбоцитів. } \\
\text { 50-70 ЕД/кг в/в болюсно, якщо плануються інгібітори GP-рецепторів IIb/IIIa } \\
\text { тромбоцитів }\end{array}$ \\
\hline Еноксапарин & 0,5 мг/кг болюсно в/в \\
\hline Бівалірудин & 0,75 мг/кг болюсно в/в з наступною інфузією 1,75 мг/кг/год до 4 год після процедури \\
\hline
\end{tabular}

Таблиця 4. Фібринолітична терапія

\begin{tabular}{|c|c|c|}
\hline Рекомендації & Клас & РД \\
\hline $\begin{array}{l}\text { Якщо фібринолізис вибраний як основна реперфузійна стратегія, рекомендується починати } \\
\text { відразу після встановлення діагнозу ГКС з елевацією ST, бажано на догоспітальному етапі }\end{array}$ & $\mathbf{I}$ & A \\
\hline Рекомендовані фібрин-специфічні препарати (альтеплаза, тенектеплаза, ретеплаза) & $\mathbf{I}$ & B \\
\hline Необхідно використовувати $1 \frac{1}{2}$ дози тенектеплази в осі6 $\geq 75$ років & Ila & B \\
\hline \multicolumn{3}{|l|}{ Антиагрегантна терапія як додаток до фібринолізу } \\
\hline Рекомендовано використання ацетилсаліцилової кислоти перорально або в/в & $\mathbf{I}$ & B \\
\hline Клопідогрель призначають додатково до ацетилсаліцилової кислоти & $\mathbf{I}$ & A \\
\hline $\begin{array}{l}\text { Подвійна антитромбоцитарна терапія (ацетилсаліцилова кислота + інгібітор Р2Y12 рецепторів) } \\
\text { показана до } 1 \text { року пацієнтам після фібринолізу з наступним ПКВ }\end{array}$ & $\mathbf{I}$ & C \\
\hline \multicolumn{3}{|l|}{ Антикоагулянтна терапія як додаток до фібринолізу } \\
\hline $\begin{array}{l}\text { Антикоагулянт призначають пацієнтам, які отримали фібриноліз до реваскуляризації, або до } \\
\text { виписки із стаціонару протягом } 8 \text { діб. Антикоагулянтом може бути: } \\
\text { - } \\
\text { - }\end{array}$ & $\begin{array}{l}\text { I } \\
\text { I }\end{array}$ & $\begin{array}{l}\text { A } \\
\text { A } \\
\text { B }\end{array}$ \\
\hline \multicolumn{3}{|l|}{ Переведення після фібринолізу } \\
\hline Всім пацієнтам негайно після фібринолізу рекомендоване переведення в ПКВ центр & I & A \\
\hline \multicolumn{3}{|l|}{ Втручання після фібринолізу } \\
\hline $\begin{array}{l}\text { Екстрена коронарографія і ПКВ за показаннями рекомендовані всім пацієнтам із серцевою } \\
\text { недостатністю/шоком }\end{array}$ & $\mathbf{I}$ & A \\
\hline $\begin{array}{l}\text { Рятівне ПКВ показане негайно після фібринолізу, якщо він був неуспішний (зниження підйому } \\
\text { сегмента ST<50 \% через 60-90 хв) або при наявності гемодинамічної чи електричної } \\
\text { нестабільності або погіршання симптомів ішемії }\end{array}$ & $\mathbf{I}$ & A \\
\hline КАГ і ПКВ рекомендовані між 2-24 год після успішного фібринолізу & $\mathbf{I}$ & A \\
\hline
\end{tabular}


Огляди літератури, оригінальні дослідження, погляд на проблему, ювілеї

Висновки. Проведений клінічний та літературний аналіз дозволяє заключити, що у нових рекомендаціях Європейського кардіологічного товариства щодо ведення пацієнтів із ГКС з елевацією сегмента ST (2017р.) відмічено існування суттєвих гендерних особливостей клінічного перебігу ГКС у жінок, що може мати негативний вплив на своєчасність діагностики цього життєво загрозливого клінічного стану і, відповідно, може

утруднювати своєчасний вибір адекватної лікувальної тактики. Одночасно в даних рекомендаціях наголошено на спільних принципах діагностики і програмах ведення для обох статей, незалежно від наявності певних гендерних розбіжностей, а також наведено перелік, показання до застосування і дози фібринолітичних, антикоагулянтних та антиагрегантних засобів з позицій доказової медицини.

\section{ЛITEPATУPA}

1. 2017 ESC Guidelines for the management of acute myocardial infarction in patients presenting with ST-segment elevation / B. Ibanez, S. James, S. Agewall [et al.] // European Heart Journal. - 2017. - Vol. 39. - P. 1-66. doi. org/10.1093/eurheartj/ehx393

2. ACS and STEMI treatment: gender-related issues / A. Chieffo, G. L. Buchanan, F. Mauri [et al.] // Eurolntervention. - 2012. - Vol. 8, Suppl. P. - P. 27-35. doi: 10.4244/ EIJV8SPA6.

3. Kawamoto K. R. Acute coronary syndromes: differences in men and women / K. R. Kawamoto, M. B. Davis, C. S. Duvernoy // Curr. Atheroscler. Rep. - 2016. - Vol. 18 (12). - P. 73.

4. GENESIS PRAXY Team. Sex differences in acute coronary syndrome symptom presentation in young patients / N. A. Khan, S. S. Daskalopoulou, I. Karp [et al.] //

JAMA Intern. Med. - 2013. - Vol. 11; 173 (20). - P. 18631871. doi: 10.1001/jamainternmed.2013.10149.

5. GENESIS PRAXY Team. Sex differences in prodromal symptoms in acute coronary syndrome in patients aged 55 years or younger / N. A. Khan, S. S. Daskalopoulou, I. Karp [et al.] // Heart. - 2017. - Vol. 103 (11). - P. 863869. doi: 10.1136/heartjnl-2016-309945. Epub 2016 Dec 13.

6. Швед М. І. Гострий коронарний синдром: гендерні відмінності крізь призму нових рекомендацій Європейського кардіологічного товариства 2017 / М. І. Швед, С. Й. Липовецька // Збірник наук. праць Всеукр.науково-практ.конфер. «Жіноче здоров'я: імплементація сучасних протоколів в клінічну практику».Тернопіль, 2018.- С.162-168.

\section{REFERENCES}

1. Ibanez, B., James, S., \& Agewall, S. (2017). 2017 ESC Guidelines for the management of acute myocardial infarction in patients presenting with ST-segment elevation. European Heart Journal, 39, 1-66.

2. Chieffo, A., Buchanan, G.L., \& Mauri, F. (2012). ACS and STEMI treatment: gender-related issues. Euro Intervention, 27-35. doi: 10.4244/EIJV8SPA6.

3. Kawamoto, K.R., Davis, M.B., \& Duvernoy, C.S. (2016). Acute coronary syndromes: differences in men and women. Curr. Atheroscler. Rep., 18 (12), 73.

4. Khan, N.A., Daskalopoulou, S.S., \& Karp, I. GENESIS PRAXY Team (2013). Sex differences in acute coronary syndrome symptom presentation in young patients. JAMA Intern. Med., 173 (20), 1863-1871. doi: 10.1001/jamainternmed.2013.10149.

5. Khan, N.A., Daskalopoulou, S.S., \& Karp, I. GENESIS PRAXY Team (2017). Sex differences in prodromal symptoms in acute coronary syndrome in patients aged 55 years or younger. Heart, 103 (11), 863-869. doi: 10.1136/ heartjnl-2016-309945. Epub 2016 Dec 13.

6. Shved, M.I., \& Lypovetska, S.Y. (2018). Hostryi koronarnyi syndrom: henderni vidminnosti kriz pryzmu novykh rekomendatsii Evropeiskoho kardiolohichnoho tovarystva [Acute coronary syndrome: gender differences in highlight of new guidelines of European society of cardiology 2017]. Zbirnyk nauk. prats Vseukr. Naukovo-prakt. Konferentsii "Zhinoche zdorovia: implementatsiia suchasnykh protokoliv v klinichnu praktyku" - Collection of Scientific Works Of AllUkrainian Scientific and Practical Conference "Women's Health: Implementation of Modern Protocols in Clinical Practice". Ternopil [in Ukrainian].

\section{К ВОПРОСУ ГЕНДЕРНЫХ ОСОБЕННОСТЕЙ КЛИНИЧЕСКОГО ТЕЧЕНИЯ И ЛЕЧЕБНОЙ ТАКТИКИ ПРИ ОСТРОМ КОРОНАРНОМ СИНДРОМЕ}

○М. И. Швед, С. И. Липовецкая, С. М. Геряк, Л. В. Левицкая

ГВУз «Тернопольский государственный медицинский университет имени И. Я. Горбачевского МЗ Украины»

РЕЗЮМЕ. Сердечно-сосудистые заболевания продолжают занимать ведущее место среди причин смертности как у мужчин, так и у женщин. Однако острый коронарный синдром у женщин часто остается до конца не диагностированным и не леченным вследствие недостаточного осознания этой проблемы самими женщинами, наличия атипичных симптомов, промедления во времени сустановлением правильного диагноза и менее частым применением инвазивных методов лечения. 
Огляди літератури, оригінальні дослідження, погляд на проблему, ювілеї

В статье освещены основные особенности клинического течения острого коронарного синдрома у женщин, в частности инфаркт миокарда без обструкции коронарных артерий. Одновременно отмечено совместные принципы диагностики и программы ведения для обоих полов, независимо от наличия определенных гендерных различий, а также приведен перечень, показания к применению и дозы фибринолитических, антикоагулянтных и антиагрегантных средств с позиций доказательной медицины.

КЛЮЧЕВЫЕ СЛОВА: острый коронарный синдром; инфаркт миокарда без обструкции коронарных артерий; перкутанные коронарные вмешательства; фибринолиз.

\section{GENDER ISSUES OF CLINICAL COURSE AND TREATMENT OF ACUTE CORONARY SYNDROME}

@M. I. Shved, S. Y. Lypovetska, S. M. Geryak, L. V. Levytska I. Horbachevsky Ternopil State Medical University

SUMMARY. Cardiovascular diseases are among leading causes of mortality in both men and women. However, acute coronary syndrome in women often remains undiagnosed and untreated due to lack of awareness of this problem by women, the presence of atypical symptoms, delay in time with the correct diagnosis and lesser use of invasive treatments.

In this article the main features of the clinical course of acute coronary syndrome in women, in particular myocardial infarction without obstruction of the coronary arteries, are highlighted. At the same time, the general principles of diagnostics and management for both sexes are emphasized, regardless of the presence of certain gender differences, as well as the list, indications for use and doses of fibrinolytic, anticoagulant and antiplatelet agents from the standpoint of evidence-based medicine.

KEY WORDS: acute coronary syndrome; myocardial infarction without obstruction of coronary arteries; percutaneous coronary intervention; fibrinolysis. 